Portland State University

PDXScholar

\title{
The Resilience of Military-Dominated Rule in Contemporary Egypt
}

Fiona R. Spring

Portland State University

Follow this and additional works at: https://pdxscholar.library.pdx.edu/honorstheses Let us know how access to this document benefits you.

\section{Recommended Citation}

Spring, Fiona R., "The Resilience of Military-Dominated Rule in Contemporary Egypt" (2020). University Honors Theses. Paper 894.

https://doi.org/10.15760/honors.915

This Thesis is brought to you for free and open access. It has been accepted for inclusion in University Honors Theses by an authorized administrator of PDXScholar. Please contact us if we can make this document more accessible: pdxscholar@pdx.edu. 
The Resilience of Military-Dominated Rule in Contemporary Egypt

by

Fiona R. Spring

An undergraduate honors thesis submitted in partial fulfillment of the requirements for the degree of

Bachelor of Arts

in

University Honors

and

Political Science

Thesis Advisor

Robert Asaadi

Portland State University 


\section{Introduction}

What factors account for the largely unmatched resilience of military control over Egyptian politics? This thesis examines the literature on civil-military relations, post-authoritarian civilianization and corporate grievance theory to explain how the Egyptian military has maintained political dominance despite repeated challenges to its authority and global trends toward political civilianization. I argue that the unique durability of military-dominated rule in Egypt is a product of a combination of country-specific factors. Firstly, the Egyptian armed forces wield a substantial amount of both hard and soft power within the country, enjoying a high degree of popularity that contributes to the depth of its influence. Secondly, a number of historical and institutional factors have fostered an environment in which the military as a corporate body has had both the motivation and the opportunity to intervene and unseat civilian leaders or other potential challengers. Thirdly, the Egyptian military's deep politicization as well as the role it played in the years following the 2011 uprisings have produced a dynamic through which its leadership has been able to resist any attempt to crack down on its significant "reserved domains" of privilege.

I will begin my argument with a summary of major Egyptian political events since the 2011 Arab Spring Revolts, followed by an explanation of the position the armed forces occupy in Egyptian politics and society. I will then go through each of the component parts of my argument in detail, applying them to the contemporary Egyptian case. Finally, I will employ two case studies - Indonesia in the late 1990s and Turkey in the mid-to-late 2000s — to illustrate my argument by way of comparison. 


\section{The Revolution and the Military}

On January 25, 2011, thousands of Egyptians poured into the streets of Cairo in a mass demonstration, igniting a popular revolt that spread across the country and culminated in the end of autocrat Hosni Mubarak's 30-year presidency. The protesters' demands were focused on political and civil liberties, government corruption, police brutality, and economic grievances. However, very few people expected that the wave of revolt would become strong enough to unseat a long-term president like Mubarak. Indeed, given the robustness and brutality of the regime's internal security forces, it is likely that the demonstrations would have been put down with little difficulty had it not been for one vital actor: the Egyptian armed forces (Kandil 2012).

The military has long played a crucial role in determining the course of Egyptian politics. Following its defection from the Mubarak regime in 2011, military leadership quickly took control of the post-uprising political environment, setting the agenda and acting as "manager" of the transition process (Roll 2016; Szmolka 2015). In 2012, Muslim Brotherhood-affiliated candidate Mohamed Morsi was elected to the presidency in what was widely considered to be the first truly competitive election in modern Egyptian history. Just over a year later, however, Morsi was removed from office in a military coup d'etat. Today, the country is led by President Abdel Fattah el-Sisi, a former general who served as Minister of Defense at the time of the 2013 coup.

\section{Military Capability and Soft Power}

Many scholars view the behavior of the Egyptian military since 2011 as part of a broad trend of military political dominance dating back to the revolution of 1952, during which a group of army officers led by future presidents Mohamed Naguib and Gamal Abdel Nasser overthrew 
King Farouk and established the Arab Republic of Egypt. As Springborg (2017) notes, the extent to which the armed forces have dominated Egyptian politics since the mid-twentieth century is largely unmatched in the world. Not only is Egypt's military one of the largest and most powerful in Africa — and indeed the world ("2019 Military Strength Ranking")—but the brief presidency of Mohamed Morsi has thus far been the only interruption in the military's control over government since the establishment of the republic. Moreover, the Egyptian state's resilient militarization has contradicted global trends toward political civilianization and dissolution of military business enterprises, even among countries with powerful militaries with high public approval ratings (Springborg 2017).

What accounts for the unique durability of political militarization in Egypt? Springborg (2017) argues that it can be partially explained by the "depth" of military rule in the country. "Depth," according to Springborg, is a combined measure of the military's manpower, firepower, economic influence, social clout, and penetration of the state via the appointment of both active-duty and retired members of the military to administrative positions.

Relatedly, Springborg focuses on the hard and soft power the armed forces have historically wielded within Egypt. He argues that hard power is what enables the military to stand up against potential challengers, but its soft power-defined as the ability to influence the thinking and perceptions of the public through ideational and material means-is the key ingredient to its ability to discourage and resist challenges to its authority. That is, by portraying itself in a positive light via media representations and educational curricula as well as fostering economic dependence through the provision of goods and services to all classes and sectors of 
society, the Egyptian military has been able to foster an environment in which opposition to military dominance is far less likely.

It is clear that the military is generally held in high esteem among the Egyptian public. According to Arab Barometer survey data, 84.3 percent of Egyptians reported trusting the armed forces to a great or medium extent (Arab Barometer V: Egypt Country Report). Similar levels of public trust in the military can be seen in the other two case studies featured in this thesis. Data from the World Values Survey show that 73 percent of Indonesians in the 1990s and 85.1 percent of Turks in the early 2000s expressed "a great deal" or "quite a lot" of confidence in the armed forces (Inglehart et al. 2014). Regardless, while the Egyptian figure is lower today than it was in 2011, when pro-democracy demonstrators could be heard chanting "the army and the people are one hand" in the streets of Cairo, it is indicative of significant support for the military despite growing political repression.

This combination of widespread public support and military firepower may partially explain the persistent political dominance of the Egyptian armed forces. However, other cases have shown that civilianization of the state is possible, even in the presence of powerful, popular, and deeply-entrenched military establishments (Tusalem 2014; Mietzner 2014). Indeed, some evidence suggests that military size, strength and/or expenditure have little to no impact on prospects for civilianization and/or democratization (McKinlay and Cohan 1975; Tusalem 2014). It therefore follows that while the military doubtlessly enjoys quite a lofty position in Egyptian society, its strength and popularity cannot be the only explanations for the resilience of its political influence.

Institutional Environments and Military Dominance 


\section{Corporate Grievance Theory}

Corporate grievance theory is an often-cited theoretical framework in the literature on civil-military relations and the durability of military-dominant rule, particularly in relation to military coups against civilian governments. The theory holds that militaries, like all bureaucratic organizations, seek resources, autonomy, and power. Coups may occur when officers perceive a threat to those interests from civilian governance. While the specific content of military corporate interests may vary from state to state, Bellin (2012) identifies three generalized components that comprise the core interests of almost every national military: maintenance of intra-military cohesion and discipline, protection of military legitimacy in the minds of the public, and the safeguarding of military economic interests - both in the form of funding for the armed forces as an institution as well as access to personal economic benefits for members of the military. According to many scholars, it therefore follows that civilian governments that cater to these interests are less coup-prone and vice-versa. On the surface, the Egyptian case appears to contradict this line of thinking, especially with regard to the military's defection from the regime in 2011.

Kandil (2012) addresses this apparent contradiction by refuting the general assumption that the military had little to complain about during the Mubarak era, contending that the supposed benefits it received were merely a mask that covered deep frustration and disenfranchisement within its ranks. In his discussion of the "myth of military privilege under Mubarak," Kandil argues that not only was the military's economic empire fairly modest relative to the country's overall economic growth, but it was dependent upon aid from the United States, a country with an interest in maintaining Israeli military superiority in the region. Furthermore, 
counterproductive to his coup-proofing attempts, Mubarak preferred to empower the police and security apparatus over the military. All of these factors worked together to produce a sense of powerlessness among the military leadership, fomenting resentment against the regime.

Bellin (2012), on the other hand, characterizes the Egyptian army's decision to defect from the regime rather than firing on protesters as one made in keeping with the military's interest in preserving its image as "defender of the nation" (131). This image - rooted in the historical legacy of the 1973 war, which many Egyptians still view as an Egyptian victory—is a key source of legitimacy for the military, allowing it significant leeway to pursue its own interests, sometimes at the expense of the public (Miller et al. 2012). Using lethal force to quell nonviolent demonstrations, Bellin argues, is particularly risky when protesters can be cast as "representative of the "nation" (131) and cannot be dismissed as members of an "otherized" minority group. This dynamic may explain why the Egyptian military opted to use deadly force against protesters in the Maspero protests of October 2011, killing 24 people, most of whom were minority Coptic Christians (Mackey 2011).

From either perspective, then, it is little surprise that the armed forces did not need much convincing to turn against the Mubarak regime in 2011. Despite initially presenting itself as a neutral player during the protests, it was not long before the Supreme Council of the Armed Forces - a previously non-political organization composed of top military officials and headed by then-Minister of Defense Hussein Tantawi-took control of the situation. The SCAF claimed that the military had staged its nonviolent intervention in accordance with the will of the people. However, Roll (2016) argues, this intervention was in fact carried out in the interest of state stability — a key interest of the military as a corporate body. While restoring and preserving its 
own autonomy lay at the core of the military's motivations during this period, increasingly intense street demonstrations as well as the growing political influence of the Muslim Brotherhood and other Islamist factions posed a challenge to stability and therefore military influence.

\section{The Military and the Transition}

Motivated by their interest in restoring the military's political influence, Roll (2016) argues, the SCAF favored an approach of "gradual change" in order to maximize their control over the transition process. This approach, he argues, is illustrated in two key decisions that functioned to preserve the military's role as "manager" of the transition as well as close off paths to future civilianization.

Firstly, Roll writes, the SCAF aimed to preserve Egypt's pre-existing legal framework as much as possible in order to prevent radical changes with the potential to detract from military autonomy, such as Mohamed Morsi's still-to-come 2012 Constitutional Declaration. Instead of beginning the transition process by electing an assembly to draft a new constitution ahead of elections, as was done in Tunisia, the SCAF opted to delay the constitution-drafting process until after elections and operate based on an amended version of the constitution of 1971. While this strategy did initially appear to function as intended, it attracted criticism over a perceived lack of transparency and may have ultimately opened the door to Morsi's far-reaching consolidation of presidential power during his time in office.

Secondly, the SCAF made the decision to appoint "technocratic" governments made up of individuals loyal to the military rather than making any attempt at inclusion or broad representation of various sectors within society. "[This] spoke to the intra-elite shifting of power 
from a network close to the family of the ousted president to one with strong connections to the military," Roll writes. "At the same time, the SCAF successfully staved off fundamental change through which actors outside the established [politically-relevant elites] might have gained access to power" (27). Relatedly, there was little change in the staffing of important state institutions under SCAF rule, particularly in the security sector, meaning that few members of the previous regime were held accountable for corruption or abuses of power. Through these strategies, Roll argues, the SCAF failed to set the stage for any type of reform at all, preferring instead to simply cement the state structures of the old regime even more firmly into place.

Other scholars, however, argue that corporate interests and/or grievances alone are not sufficient to explain military intervention or resistance to civilianization —opportunity must also be present. Factors that can expand or constrain military corporate opportunity are many and varied. Focusing on military coups in post-authoritarian contexts, Bou Nassif (2017) argues that even if officers feel that their interests are compromised or they are ideationally opposed to the new political order, intervention is unlikely if political parties are united in opposition to military rule, as in Chile during the post-Pinochet period. In some post-transitional contexts, on the other hand, certain parties may dominate the political scene, failing to form coalitions and sidelining other parties. This produces polarization and political paralysis among civilian political leadership, granting an advantage to the military if they should feel the motivation to intervene.

\section{Military Identity}

\section{Politicization}

Another important factor in evaluating military corporate opportunity is military politicization, or the degree to which retired and active-duty members of military leadership are 
directly involved in politics, often by occupying positions in government. Tusalem (2014) presents evidence that in post-authoritarian contexts, countries with highly-politicized militaries—-such as Egypt—are considered to be more resistant to civilianization and democratization. Further, the legacies of historically interventionist militaries may be damaging to states' prospects for civilianization. In such contexts, Tusalem argues, a vital step in the civilianization process is the elimination of so-called "reserved domains" of military privilege. The specific content of these reserved domains vary from country to country, but may include limitations on the powers of the president or legislature to direct military affairs, reserved positions in executive cabinets for members of the military, immunities for military members from being prosecuted in civilian courts, sole authority for military leadership over military staffing and budgetary decisions, and amnesty for former officers accused of committing human rights violations in the past. For example, while post-authoritarian Argentina and Bolivia experienced rapid civilianization and democratic consolidation after cracking down on such domains, many African cases failed to do so and continue to experience the legacies of military-dominated rule.

Reserved Domains in the 2014 Constitution

In his conclusion, Tusalem poses the question of how his theory may be applied to the cases of Egypt and Tunisia in the years following their revolutions: to what degree have each of these countries succeeded in cracking down on reserved domains of military privilege, and what impact has this crackdown (or lack thereof) had on the role of the military in governance?

As previously mentioned, the SCAF's influence over the post-uprising transition resulted in a number of provisions beneficial to the military as an organization, largely related to the 
appointment of government officials and staffing of the security sector (Roll 2016). In addition, an examination of the 2014 Egyptian constitution reveals a number of features that serve to strengthen the military—albeit largely indirectly through the presidency.

The Egyptian armed forces' influence over the political arena has historically been channelled through control over the executive branch (Heliotis 2014; Miller et al. 2012). Given this dynamic, it follows that in the Egyptian context, a powerful presidency equals a powerful military. Despite its surface-level focus on social justice and human rights, this is exactly what the 2014 constitution works to do-empower the executive branch and the military in order to consolidate state power and reinforce the durability of the current military-dominated regime (Al-Ali 2016; Brown 2014).

Al-Ali (2016) discusses at length the degree to which the 2014 constitution shifts the balance of power in the Egyptian government to favor the president while weakening the power of the legislature. Article 146, for example, grants the president the authority to nominate his own candidate for the prime ministership, who is then subject to approval by the parliament. If the president's nominee fails to gain parliamentary confidence, the president must then nominate the candidate of the largest parliamentary bloc. The parliament is dissolved if this second candidate fails to obtain confidence. This arrangement, Al-Ali argues, places the parliament in a position subordinate to the president by placing great pressure on legislators to accept the president's chosen candidate, thereby granting the president undue influence over parliamentary affairs and creating the potential for abuses of power.

Al-Ali also raises concern over the 2014 constitution's requirements regarding states of emergency. Firstly, the acceptable reasons for declaring a state of emergency are not enumerated 
in the constitution, meaning the president may declare a state of emergency for any reason, as long as he consults his cabinet. Secondly, although the constitution limits the length of a presidentially-declared state of emergency to three months, Al-Ali argues that its stipulated renewal process is questionable. While the 2012 constitution required that states of emergency could only be renewed via public referendum, states of emergency under the 2014 constitution may be renewed with the approval of a majority of members of parliament. Given the subordinate position of the legislature to the president, this process could arguably make renewal much easier and allow states of emergency—and the associated expansion of executive authority— to continue for much longer.

In addition to expanding executive authority, the 2014 constitution also contains a number of articles that directly expand the autonomy of the military and insulate it from civilian oversight. Firstly, unlike in previous constitutions, the Minister of Defense serves as commander in chief of the armed forces. Any candidate for this position must be approved by the military high command (Brown 2014; Heliotis 2014). Additionally, article 203 establishes a National Defense Council charged with the responsibility of approving the military budget as a "single figure," thereby effectively insulating budgetary decisions from public oversight.

One point of disagreement among analysts of the 2014 constitution is related to its provisions regarding military courts. Article 204 allows for the continued existence of military courts that "[adjudicate] exclusively in all crimes related to the armed forces, its officers, personnel, and their equals, and in the crimes committed by general intelligence personnel during and because of the service," and limits the circumstances under which civilians can be tried by military courts to: 
crimes that represent a direct assault against military facilities, military barracks, or whatever falls under their authority; stipulated military or border zones; its equipment, vehicles, weapons, ammunition, documents, military secrets, public funds or military factories; crimes related to conscription; or crimes that represent a direct assault against its officers or personnel because of the performance of their duties.

Heliotis (2014) views this provision as an important check on the military's

constitutionally-granted power because of the specific limitations on civilian trials in military courts. Brown (2014), however, argues that these limitations are too vague and potentially expansive to be truly effective in curtailing the military's power to abuse the judicial system. "What is presented as a restrictive clause," he writes, "is actually likely to be an alarmingly enabling one." (4)

Regardless of debate over the military judiciary provision, however, an analysis of the Egyptian Constitution of 2014 reveals that very little has been done to eliminate or weaken the military's reserved domains of privilege. Especially compared to the far less military-friendly constitution of 2012, it is clear that the Egyptian military's high degree of politicization has allowed it to control the post-uprising transition process to a sufficiently close degree to reestablish and more deeply entrench its dominance over the Egyptian political system and strengthen its own position against any potential challengers.

\section{Analysis}

The resilience of military-dominated rule in contemporary Egypt, then, can be at least partially explained as a product of three interrelated variables: military capability, institutional environment, and military identity. In the context of this thesis, military capability refers not to the size or firepower of the military, but to its levels of soft power, internal cohesion, and public trust. Institutional environment refers to the degree to which state institutions empower the 
military to pursue its interests as a corporate body. Military-friendly institutional features may include executive supremacy over other branches of government as well as other previously-mentioned reserved domains of military privilege. Military identity refers to the degree to which a military can be seen as politicized versus professionalized.

When military capability is high, institutional environments are military-friendly, and military identity is politicized, civilianization is less likely, and vice versa (see Fig. 1). In Egypt, as I have shown, all three variables work together to produce a political environment in which military-centered rule is cemented firmly in place (see Fig. 2). However, it logically follows that as these variables shift, so too does the likelihood of civilianization. In the following section, I will apply this theory to two other cases in order to demonstrate how these three variables may be predictive of future civilianization across various contexts.

\begin{tabular}{|c|c|c|}
\hline & Civilianization Likely & Civilianization Unlikely \\
\hline Military Capability (High) & $\mathrm{X}$ & $\mathrm{X}$ \\
\hline Military Capability (Low) & $\mathrm{X}$ & \\
\hline $\begin{array}{c}\text { Institutional Environment } \\
\text { (Friendly) }\end{array}$ & $\mathrm{X}$ \\
\hline $\begin{array}{c}\text { Institutional Environment } \\
\text { (Unfriendly) }\end{array}$ & $\mathrm{X}$ & \\
\hline Military Identity (Politicized) & & \\
\hline $\begin{array}{c}\text { Military Identity } \\
\text { (Professionalized) }\end{array}$ & & \\
\hline
\end{tabular}

Fig. 1-Generalized Case 


\begin{tabular}{|c|c|c|}
\hline & Civilianization Likely & Civilianization Unlikely \\
\hline Military Capability (High) & & $\mathrm{X}$ \\
\hline $\begin{array}{c}\text { Institutional Environment } \\
\text { (Friendly) }\end{array}$ & $\mathrm{X}$ \\
\hline Military Identity (Politicized) & & $\mathrm{X}$ \\
\hline
\end{tabular}

Fig. 2-Egypt, 2011-Present

\section{Case Studies}

It is clear that the Egyptian armed forces are deeply intertwined with the Egyptian state and wield enormous influence over politics and society. However, a number of cases in recent decades have demonstrated that it is indeed possible to marginalize even the most powerful and popular militaries in favor of civilian rule. In this section, I will examine just two of those cases, comparing them to the contemporary Egyptian case and exploring how they may or may not serve as models for the future civilianization of the Egyptian state.

Indonesia, 1998

In an illustrative comparative case study of the post-authoritarian experiences of Egypt and Indonesia, Mietzner (2014) argues that despite their similar political and cultural trajectories between the 1950s and 1990s, a number of specific and interrelated factors produced vastly divergent outcomes between the two countries with regard to the marginalization of the military and civilianization of the state. As the author points out, both countries were - and are-Muslim-majority societies with significant religious minorities, both had legacies of deep military involvement in politics, and both experienced waves of popular protests that resulted in withdrawal of military support from the regime and the subsequent resignation of long-term, "sultanistic" presidents, both of whom were ex-generals. 
Mietzner's explanation for these divergent outcomes relies partially on military popularity, but also on institutional factors and balances of power during the transition process. While the Indonesian military played a central role in the repression of the opposition during the period of mass demonstrations, Mubarak's primary apparatus of repression was the Ministry of the Interior, which oversaw the police, the Central Security Forces, and the State Security Investigations Service. This allowed the Egyptian military's reputation to remain relatively intact following Mubarak's ouster. Therefore, while the "discredited" Indonesian military was largely sidelined during the transition period, its Egyptian counterpart was able to play a central role in the post-authoritarian political arena.

In response to pressure from the Indonesian student movement, ousted Indonesian president Suharto transferred power to vice president B.J. Habibie, who went on to manage the transition in a way that supported the civilianization process. In Egypt, on the other hand, top military leadership quickly took control of the transition - perhaps due in part to the military's intact popularity in the wake of the 25 January Revolution — taking quick action to consolidate power and establish a number of institutional measures that severely limited prospects for future civilianization or democratization (Mietzner 2014, Roll 2016).

In the Indonesian case, therefore, two of the three variables I identify in this argument shifted to increase the likelihood of civilianization: the military's capability was reduced by way of diminished public trust as a result of its participation in the repression of demonstrations, and the military-friendliness of the transitional institutional environment was limited by the transfer of power to the vice president rather than the military leadership. While military politicization 
remained unchanged, changes in two out of three variables were sufficient to shift the balance of power away from military leadership in favor of civilian government (see Fig. 3).

\begin{tabular}{|c|c|c|}
\hline & Civilianization Likely & Civilianization Unlikely \\
\hline Military Capability (Reduced) & $\mathrm{X}$ & \\
\hline $\begin{array}{c}\text { Institutional Environment } \\
\text { (Less Friendly) }\end{array}$ & $\mathrm{X}$ & \\
\hline Military Identity (Politicized) & & $\mathrm{X}$ \\
\hline
\end{tabular}

Fig. 3-Indonesia, 1998

While the Indonesian case is helpful in understanding why and how the Egyptian military was able to regain power following the 2011 uprisings and Morsi's ouster, it has little power in the way of providing a model for future civilianization. While the transitional period may have presented a short window of time during which institutional reform favoring civilianization could have occurred, the current pro-military institutions have at this point been established and consolidated. For this reason, it may be helpful to examine a case in which the military was marginalized without the need for regime change.

Turkey, 2007-2013

A second interesting case of the marginalization of a historically powerful and influential military establishment is that of the Turkish military in the early twenty-first century. Since the establishment of the Turkish republic by Mustafa Kemal Ataturk in 1923, the armed forces have played a vital role in Turkish politics. While active-duty members of the military are barred from engaging directly in politics, the armed forces as an organization have long been portrayed as the "guardians" of the constitution and "the only capable and incorruptible institution to which the regime could be entrusted" (Kadercan and Kadercan 2016, 86). This notion of 
guardianship - similar in some ways to the conception of the Egyptian armed forces as the guardian of the people — granted the Turkish military the social and political influence to stage four coups between 1960 and 1997.

By the time of the Gezi Park protests of 2013 however, Kadercan and Kadercan (2016) argue that the political clout of the Turkish armed forces had been "literally shattered" (84). Between 2007 and 2013, they argue, the military had become the victim of what the authors refer to as a "countercoup" consisting of a series of trials and public relations campaigns that severely damaged its capacity to influence politics as it had in the past. This countercoup was born from the rise of the Adalet ve Kalkınma Partisi (AKP)—Justice and Development Party in English—beginning in the early 2000s. As tensions grew between the Turkish Armed Forces and the AKP reached a boiling point, the authors argue, the "agile" party was able to catch the "slow" military establishment off guard, ultimately effectively ousting the latter from politics.

This case demonstrates that military marginalization can occur even when only the institutional environment is shifted in favor of civilianization (see Fig. 4). As the AKP came to power, the military was suddenly confronted with a new and formidable rival—something it was not prepared to confront.

\begin{tabular}{|c|c|c|}
\hline & Civilianization Likely & Civilianization Unlikely \\
\hline Military Capability (High) & & $\mathrm{X}$ \\
\hline $\begin{array}{c}\text { Institutional Environment } \\
\text { (Reduced) }\end{array}$ & $\mathrm{X}$ & \\
\hline Military Identity (Politicized) & & $\mathrm{X}$ \\
\hline
\end{tabular}

Fig. 4-Turkey 2007-2013 
As the Turkish case shows, the authors argue, such countercoups may be successful in marginalizing politically strong military establishments when the military in question has “internalize[d] intervention and interference in politics as part of [its] 'normal' functions" (89) and become overly bureaucratic, contributing to a level of organizational transparency that makes it vulnerable to political actors who may have an interest in undermining its power. This dynamic, I believe, presents a potentially viable future path to civilianization in Egypt. However, it would require time and specific decisions on the part of the military, but a sufficiently powerful political actor with an interest in marginalizing the military leadership. Given Egypt's infamously limited tolerance for civil society organizations and its often-brutal repression of opposition parties such as the Muslim Brotherhood's Freedom and Justice Party, this is unlikely to occur in the near future.

Additionally, it is important to note that, as the Turkish case demonstrates, democratization does not necessarily come with the marginalization of a politically dominant military. On the contrary, as Bargu (2018) argues, the present conflict between the Turkish Armed Forces and the ruling AKP has precipitated an authoritarian backslide in the country. This presents additional challenges for Egypt - a country which has never been considered democratic, despite the pro-democratic nature of the 2011 protests - in the case of potential civilianization. As with the AKP in the Turkish case, it is possible that a political actor with sufficient power to marginalize the military may also have the power to re-centralize power around itself, thereby reproducing the authoritarian nature of military-dominated rule.

\section{Conclusion}


I have identified three variables that contribute to the resilience of military-dominated rule in contemporary Egypt and that may be applied to other cases to predict the likelihood of marginalization of a powerful military and/or civilianization of the state: military capability, institutional environments, and military identity. Although none of these variables are sufficient alone to predict civilianization or continued military-dominated rule, they may work together to produce political environments that make civilianization more or less likely.

Although this thesis briefly explores a limited number of case studies outside contemporary Egypt, it is not expansive enough to have much predictive power outside of the Egyptian case. Further research is needed on the broader applicability of this and other theories of military-dominated rule and post-authoritarian civilianization. Future research may attempt to address similar questions of how and why certain militaries remain dominant while others are marginalized in favor of civilian government, but should use larger sample sizes to attempt to identify historical and contemporary trends. Attention should also be paid to the still-developing Turkish case as the political landscape continues to shift. 


\section{References}

“2019 Military Strength Ranking." Global Firepower.

https://www.globalfirepower.com/countries-listing.asp.

Arab Barometer V: Egypt Country Report. 2019.

https://www.arabbarometer.org/wp-content/uploads/ABV_Egypt_Report_Public-Opini on_Arab-Barometer_2019.pdf.

Bargu, Banu. 2018. "Year One: Reflections on Turkey's Second Founding and the Politics of Division." Critical Times 1(1): 23-48. https://doi.org/10.1215/26410478-1.1.23.

Bellin, Eva. 2012. "Reconsidering the Robustness of Authoritarianism in the Middle East: Lessons from the Arab Spring." Comparative Politics 44(2): 127-49. http://www.jstor.org/stable/23211807.

Bou Nassif, Hicham. 2017. "Coups and Nascent Democracies: The Military and Egypt's Failed Consolidation." Democratization 24(1): 157-74. https://doi.org/10.1080/13510347.2016.1142533.

Brown, Nathan J. "Egypt's constitutional cul-de-sac: Enabling military oversight and a security state in a nominally democratic order." CMI Insight (2014).

Heliotis, Nicolas B. T. - International Lawyer. 2014. "A Textual Analysis of Presidential Power under the 2014 Egyptian Constitution." International Lawyer 48(2): 127+. https://ink.gale.com/apps/doc/A452881654/GRNR?u=s1185784\&sid=GRNR\&xid=d7 701759.

Inglehart, R., C. Haerpfer, A. Moreno, C. Welzel, K. Kizilova, J. Diez-Medrano, M. Lagos, P. Norris, E. Ponarin \& B. Puranen et al. (eds.). 2014. World Values Survey: All Rounds - Country-Pooled Datafile 1981-2014. Madrid: JD Systems Institute. Version:http://www.worldvaluessurvey.org/WVSDocumentationWV

Kadercan, Pelin Telseren, and Burak Kadercan. 2016. "The Turkish Military as a Political Actor: Its Rise and Fall.” Middle East Policy 23(3): 84-99. https://doi.org/10.1111/mepo.12219.

Kandil, Hazem. 2012. Soldiers, Spies, and Statesmen : Egypt's Road to Revolt. London: Verso.

Mackey, Robert. 2011. "Social Media Accounts of Violence in Cairo Challenge Official Narrative." The New York Times. 
https://thelede.blogs.nytimes.com/2011/10/10/social-media-accounts-of-violence-in-ca iro-challenge-official-narrative/.

McKinlay, R. D., and A. S. Cohan. 1975. "A Comparative Analysis of the Political and Economic Performance of Military and Civilian Regimes: A Cross-National Aggregate Study." Comparative Politics 8(1): 1-30. http://www.jstor.org/stable/421451.

Mietzner, Marcus. 2014. "Successful and Failed Democratic Transitions from Military Rule in Majority Muslim Societies: The Cases of Indonesia and Egypt." Contemporary Politics 20(4): 435-52. http://stats.lib.pdx.edu/proxy.php?url=http://search.proquest.com/docview/1667946376 ?accountid $=13265 \% 0 \mathrm{~A}$.

Miller, Laurel E. et al. 2012. Democratization in the Arab World: Prospects and Lessons from Around the Globe. RAND Corporation. http://www.jstor.org/stable/10.7249/mg1192rc.

Roll, Stephan. 2016. "Managing Change: How Egypt's Military Leadership Shaped the Transformation." Mediterranean Politics 21(1): 23-43.

Szmolka, Inmaculada. 2015. "Exclusionary and Non-Consensual Transitions Versus Inclusive and Consensual Democratizations: The Cases of Egypt and Tunisia." Arab Studies Quarterly 37(1): 73-95.

http://stats.lib.pdx.edu/proxy.php?url=http://search.ebscohost.com/login.aspx?direct=tr $\mathrm{ue} \& \mathrm{db}=\mathrm{aph} \& \mathrm{AN}=101983380 \&$ site $=$ ehost-live.

Springborg, Robert. 2017. "The Rewards of Failure: Persisting Military Rule in Egypt." British Journal of Middle Eastern Studies 44(4): 478-96. https://doi.org/10.1080/13530194.2017.1363956.

Tusalem, Rollin F. 2014. "Bringing the Military Back in: The Politicisation of the Military and Its Effect on Democratic Consolidation." International Political Science Review / Revue internationale de science politique 35(4): 482-501.

http://www.jstor.org/stable/24573453. 